\title{
Kinetics of nitrogen transfer across the rumen wall of sheep given a low-protein roughage
}

\author{
By S. A. NEUTZE AND R. C. KELLAWAY* \\ Department of Animal Husbandry, University of Sydney, Camden, New South Wales \\ 2570, Australia \\ AND G. J. FAICHNEY \\ Division of Animal Production, CSIRO, PO Box 239, Blacktown, New South Wales 2148, \\ Australia
}

(Received 14 March 1986 - Accepted 15 May 1986)

1. The significance of blood urea-nitrogen transfer to the rumen was examined in sheep given alkali-treated wheat straw supplemented with 3.5 (diet A), 5.9 (diet B) and 11.6 (diet C) g urea-N/kg dry matter (DM).

2. Mean voluntary intakes of DM (g/d) were 897,1149 and 1225 for diets $A, B$ and $C$ respectively, indicating significant $(P<0.05)$ intake responses to urea supplementation. Digestion studies were conducted at $90 \%$ of voluntary intake. Dietary $\mathrm{N}$ intakes $(\mathrm{g} / \mathrm{d}$ ) were $7 \cdot 1,11.5$ and 18.6 for diets $\mathrm{A}, \mathrm{B}$ and $\mathrm{C}$ respectively.

3. Absorption of ammonia-N from the rumen $(\mathrm{g} / \mathrm{d})$ was $3.5,6.7$ and 8.9 for diets $\mathrm{A}, \mathrm{B}$ and $\mathrm{C}$ respectively, with all dietary differences being significantly different $(P<0.05)$.

4. Non-ammonia-N (NAN) leaving the abomasum (g/d) was $9 \cdot 6,12.7$ and 14.8 for diets A, B and C respectively. Microbial $\mathrm{N}$ leaving the abomasum $(\mathrm{g} / \mathrm{d})$ was $6 \cdot 8,9.6$ and 10.7 for diets $\mathrm{A}, \mathrm{B}$ and $\mathrm{C}$ respectively. Hence, significantly $(P<0.05)$ more $\mathrm{N}$ was provided to the intestines with increased urea supplementation. Net efficiencies of microbial protein synthesis ( $\mathrm{g} \mathrm{N} / \mathrm{kg}$ organic matter apparently digested in the rumen), estimated from ${ }^{15} \mathrm{~N}$ incorporation, were $24 \cdot 2,23.7$ and $25 \cdot 3$ for diets $\mathrm{A}, \mathrm{B}$ and $\mathrm{C}$ respectively, and were not significantly different $(P>0.05)$.

5. Calculated proportions of microbial $\mathrm{N}$ derived from rumen $\mathrm{NH}_{3}-\mathrm{N}$ were $1.05,0.95$ and 0.91 for diets $A$, $B$ and $C$ respectively, reflecting the high proportion of total $\mathrm{N}$ as urea- $\mathrm{N}$ in the diets. Proportions of microbial $\mathrm{N}$ derived from blood urea- $\mathrm{N}$ were $0.31,0.21$ and 0.12 for diets $\mathrm{A}, \mathrm{B}$ and $\mathrm{C}$ respectively, indicating a decreasing significance of blood urea as a source of microbial $\mathrm{N}$ as dietary urea increased $(P<0.05)$.

6. Transfer of blood urea- $\mathrm{N}$ to the rumen $(\mathrm{g} / \mathrm{d})$ was $3 \cdot 8,4 \cdot 7$ and 2.6 for diets $\mathrm{A}, \mathrm{B}$ and $\mathrm{C}$ respectively, being significantly $(P<0.05)$ lower on diet $\mathrm{C}$. Using an estimate of the salivary contribution of urea- $\mathrm{N}$ to the rumen, it was concluded that there was a significant though not large transfer of blood urea- $\mathrm{N}$ across the rumen wall on all diets.

7. Net transfer of blood urea- $\mathrm{N}$ to the rumen was estimated from a two-pool model and was $+0.4 \mathrm{~g} / \mathrm{d}$ for diet $\mathrm{A}$, though this was not significantly different from zero. Net transfers for diets $\mathrm{B}$ and $\mathrm{C}$ were $-2 \cdot 0$ and $-6 \cdot 3 \mathrm{~g} \mathrm{~N} / \mathrm{d}$ respectively.

8. Significant intake responses to exogenous urea supplementation were observed because of a limited capacity to recycle $\mathrm{N}$ to the rumen under the conditions of low dietary $\mathrm{N}$ supply imposed.

Nitrogen is frequently a major limiting nutrient for ruminants especially when they are given diets of mature herbage. The extent to which sheep or cattle are able to recycle urea- $\mathrm{N}$ from the blood to the rumen for utilization in the production of microbial protein could have an important influence on animal survival under conditions of severe $\mathrm{N}$ limitation. Opinions in the literature indicate some disagreement with respect to the quantitative value of this recycling mechanism to the animal. Nolan and co-workers (Nolan \& Leng, 1972; Nolan et al. 1976; Nolan \& Stachiw, 1979) have reported that only small quantities of blood urea-N entered the rumen in sheep given lucerne (Medicago sativa) chaff or wheat straw. In contrast, the results of Kennedy \& Milligan $(1978 b, c)$ for sheep given brome grass (Bromus inermis) pellets indicated that substantial quantities of blood urea-N were transferred directly across the rumen wall.

The present experiment was designed to examine the quantitative significance to sheep

* For reprints. 
Table 1. Nutrient supplementation of alkali-treated wheat straw (/kg dry matter $(D M))$

\begin{tabular}{llll}
\hline \hline Diet $\ldots$ & A & B & C \\
\hline $\mathrm{N}$ (as urea) (g) & $3 \cdot 5$ & $5 \cdot 9$ & $11 \cdot 6$ \\
Sulphur (as 98\% $\left.\mathrm{H}_{2} \mathrm{SO}_{4}\right)(\mathrm{g})$ & $0 \cdot 36$ & $0 \cdot 80$ & $1 \cdot 60$ \\
Calcium (as $\left.\mathrm{CaHPO}_{4} .2 \mathrm{H}_{2} \mathrm{O}\right)(\mathrm{g})$ & $4 \cdot 0$ & $4 \cdot 0$ & $4 \cdot 0$ \\
Phosphorus (as $\left.\mathrm{CaHPO}_{4} .2 \mathrm{H}_{2} \mathrm{O}\right)(\mathrm{g})$ & $3 \cdot 1$ & $3 \cdot 1$ & $3 \cdot 1$ \\
Copper (as $\left.\mathrm{CuSO}_{4} .5 \mathrm{H}_{2} \mathrm{O}\right)(\mathrm{mg})$ & $2 \cdot 6$ & $2 \cdot 6$ & $2 \cdot 6$ \\
Cobalt (as $\left.\mathrm{CoCl}_{2} .6 \mathrm{H}_{2} \mathrm{O}\right)(\mathrm{mg})$ & $0 \cdot 11$ & $0 \cdot 11$ & $0 \cdot 11$ \\
\hline
\end{tabular}

of urea recycling when given a basal diet of alkali-treated wheat straw supplemented with three different levels of urea. A preliminary report of this work has been published (Neutze et al. 1984).

\section{EXPERIMENTAL}

\section{Animals and management}

Six Merino or Merino-cross wethers (35-45 kg live weight), fitted with cannulas in the rumen and in the abomasum close to the pylorus were used. They were maintained in metabolism cages in a fully enclosed animal house. Continuous lighting was used and temperature was maintained between 15 and $25^{\circ}$.

\section{Diets}

Alkali-treated wheat straw was prepared by applying $45 \mathrm{~g}$ sodium hydroxide $/ \mathrm{kg}$ straw dry matter (DM), with water being added to give a final moisture content of $200 \mathrm{~g} / \mathrm{kg}$ DM. Diets A, B and C were prepared by spraying the straw with the nutrients shown in Table 1.

The amounts of urea- $\mathrm{N}$ sprayed on to the straw were $3.6,8.0$ and $16.0 \mathrm{~g} / \mathrm{kg} \mathrm{DM}$ on treatments $\mathrm{A}, \mathrm{B}$ and $\mathrm{C}$ respectively. There were losses of urea-N between spraying and feeding so that the amounts at the time of feeding were $3.5,5.9$ and $11.6 \mathrm{~g} / \mathrm{kg}$ DM on the respective treatments. Diets $\mathrm{A}, \mathrm{B}$ and $\mathrm{C}$ also contained $(/ \mathrm{kg} \mathrm{DM})$ respectively $8 \cdot 8,11 \cdot 2$ and $16.9 \mathrm{~g} \mathrm{~N} ; 872,883$ and $883 \mathrm{~g}$ organic matter $(\mathrm{OM})$, and $52 \cdot 7,52 \cdot 2$ and $51.9 \mathrm{~g}$ acid-detergent lignin (ADL). The sheep were offered feed ad lib. at 3-h intervals for the first $10 \mathrm{~d}$ of each $28 \mathrm{~d}$ experimental period. The quantity of feed offered to each sheep was adjusted daily to maintain refusals at $10-20 \%$ of the amount offered. From day 11 , i.e. for digestion and isotope studies, feed intake was maintained at $90 \%$ of their voluntary intake, by taking the mean intake over days 7-10 (inclusive).

\section{Marker infusions}

All infusions were administered by means of a portable infusion pump ('Siropump'; Everest Electronics, Seaford, South Australia). [ $\left.{ }^{15} \mathrm{~N}\right]$ urea (95 atoms \% excess) was infused into the jugular vein at a constant rate from 21.30 hours on day 17 to 23.30 hours on day 20. After allowing sufficient time for pool enrichments to return to background, ${ }^{15} \mathrm{NH}_{4} \mathrm{Cl}$ ( 95 or 99 atoms \% excess) was infused intraruminally from 21.30 hours on day 23 to 23.30 hours on day 26.

The 'double-marker' system (Faichney, 1975a, 1980) was used to measure digesta flow. The markers used were ${ }^{51} \mathrm{CrEDTA}$ (Downes \& McDonald, 1964) $\left(48 \mu \mathrm{Ci}{ }^{51} \mathrm{Cr} / \mathrm{d}\right.$ ) which remains in solution, and ${ }^{103} \mathrm{Ru}$-labelled Tris-(1,10-phenanthroline)-ruthenium (II) chloride $\left({ }^{103} \mathrm{Ru}-\mathrm{P}\right)$ (Tan et al. 1971) $\left(9 \cdot 6 \mu \mathrm{Ci}{ }^{103} \mathrm{Ru} / \mathrm{d}\right)$ which associates with particulate matter. Following a priming dose, the markers were infused into the rumen from days 20 to 27 . 


\section{Sampling and sample preparations}

Composite samples of feed ( $3 \%$ daily intake) and all feed refusals were bulked from days 14 to 24 inclusive. Feed samples were dried at $50^{\circ}$ for $48 \mathrm{~h}$, ground and stored at room temperature. On each of days 14 and 15 , three rumen digesta samples and two jugular blood samples were taken at each of $0.5,1.5$ and $2.5 \mathrm{~h}$ after feeding (i.e. nine rumen digesta samples and six blood samples) and bulked to allow estimation of $\mathrm{N}$ content and background ${ }^{15} \mathrm{~N}$ enrichment of the rumen $\mathrm{NH}_{3}-\mathrm{N}$, rumen bacterial- $\mathrm{N}$ and blood urea- $\mathrm{N}$ pools.

Rumen digesta samples were squeezed through Terylene cloth $(150 \mu \mathrm{m})$ (Weston \& Hogan, 1967), the fluid $\mathrm{pH}$ recorded, and half the fluid acidified to $<\mathrm{pH} 2$ with ten drops of concentrated sulphuric acid and stored at $-10^{\circ}$. The remaining squeezed solids were rinsed vigorously with isotonic saline ( $9 \mathrm{~g}$ sodium choloride/l), re-squeezed and added to the remaining fluid for bacterial isolation. Samples were centrifuged at $580 \mathrm{~g}$ for $10 \mathrm{~min}$ and the supernatant fraction then spun at $2400 \mathrm{~g}$ for $15 \mathrm{~min}$. The pellet was re-suspended in Brij-saline $(0.5 \mathrm{ml}$ Brij $(300 \mathrm{~g} / \mathrm{l}) / 1$ saline $(9 \mathrm{~g}$ sodium chloride/1)) and spun again at $2400 \mathrm{~g}$ for $15 \mathrm{~min}$. This latter procedure was repeated and the final pellet suspended in distilled water. Finally, samples were dried in a forced-draught oven at $50^{\circ}$ for $24 \mathrm{~h}$ and stored at room temperature. Blood samples were deproteinized by centrifugation after addition of sulphosalycylic acid $\left(25 \mathrm{mg} / \mathrm{ml}\right.$ blood) and stored at $-10^{\circ}$. Total faecal and urine collections were made from days 18 to 25 . Urine was collected into a closed bucket containing sufficient $6 \mathrm{M}$-hydrochloric acid to maintain the $\mathrm{pH}$ below 2. Faeces were collected directly into a plastic bag attached around the anus. Faeces were bulked and stored at $-10^{\circ}$ before subsampling, oven-drying at $50^{\circ}$, grinding and storage at room temperature. Of the daily output of urine $20 \mathrm{ml} / 1$ were bulked for each sheep and stored at $4^{\circ}$.

After allowing $36 \mathrm{~h}$ from the start of the $\left[{ }^{15} \mathrm{~N}\right]$ urea infusion for attainment of steady-state conditions, rumen digesta samples and blood samples were taken as described for days 14-15. Sampling during the infusion of ${ }^{15} \mathrm{NH}_{4} \mathrm{Cl}$ was as for the intravenous infusion except that, in addition, three abomasal samples were taken concurrently with the rumen samples. Samples of abomasal digesta and of fluid obtained from the digesta by straining through Terylene cloth (Weston \& Hogan, 1967) were combined and stored at $-10^{\circ}$ to provide bulk samples for each sheep. After termination of the ${ }^{103} \mathrm{Ru}-\mathrm{P} /{ }^{51} \mathrm{Cr}$-EDTA infusion, samples were taken at $09.00,12.30,16.30$ and 20.30 hours on each of the following $2 \mathrm{~d}$ for the estimation of marker mean retention times (MRT) (Faichney, 1975a). These marker dilution samples $(300 \mathrm{ml})$ were stored at $-10^{\circ}$ and assayed as soon as possible for ${ }^{103} \mathrm{Ru}$ and ${ }^{51} \mathrm{Cr}$. The concentrations of ${ }^{51} \mathrm{CrEDTA}$ were corrected for absorption (Faichney $1975 \mathrm{~b}$, 1980). At 08.30 hours on day 1 , a single large sample $(250 \mathrm{ml})$ of rumen digesta was taken to determine the diaminopimelic acid (DAPA) and $\mathrm{N}$ contents of rumen bacteria for the previous period.

\section{Chemical analyses}

$\mathrm{DM}$ and $\mathrm{OM}$ were determined by oven-drying at $105^{\circ}$ (digesta) or $50^{\circ}$ (feed and faeces) then ashing in a muffle furnace at $550^{\circ}$ for 3-4 h (Faichney \& White, 1983). ADL was determined according to Van Soest (1963) and $\mathrm{N}$ by a micro-Kjeldahl procedure using selenium as a catalyst. Methods for $\mathrm{NH}_{3}$ and urea were adapted from Chaney \& Marbach (1962) and Wilson (1966) respectively. DAPA was determined as described by Hutton et al. (1971) using a TSM automated amino acid analyser (Technicon Instruments Corporation, New York). Carrier CrEDTA was prepared according to Binnerts et al. (1968) and ${ }^{103} \mathrm{Ru}-\mathrm{P}$ according to Tan et al. (1971). ${ }^{103} \mathrm{Ru}$ and ${ }^{51} \mathrm{Cr}$ activities were determined on a Model 5210 Autogamma Scintillation Spectrometer (Packard Instrument Co. Inc., Illinois, USA). 
Samples of rumen fluid and bacteria, abomasal digesta and blood were prepared for ${ }^{15} \mathrm{~N}$ analysis using the methods described by Nolan \& Leng (1972) with minor modifications (S. Stachiw and J. V. Nolan, personal communication). ${ }^{15} \mathrm{~N}$ content was measured using a Model MSIOS mass spectrometer (GEC-AEI (Electronics) Ltd, Manchester). The mean abundance of ${ }^{15} \mathrm{~N}$ in $\left(\mathrm{NH}_{4}\right)_{2} \mathrm{SO}_{4}$ (AR grade), estimated on 203 occasions over $6 \mathrm{~d}$ was 0.366 (SE 0.0013 ) atoms $\%{ }^{15} \mathrm{~N}$. The coefficient of variation associated with measurement of abundance in a standard sample of $\left(\mathrm{NH}_{4}\right)_{2} \mathrm{SO}_{4}$ was $0.35 \%$.

\section{${ }^{15} \mathrm{~N}$ calculations}

Irreversible loss rates were calculated as described by White et al. (1969). $\mathrm{N}$ transfer between the rumen $\mathrm{NH}_{3}-\mathrm{N}$ and blood urea- $\mathrm{N}$ pools were calculated using a two-pool model (Nolan et al. 1976; Kennedy \& Milligan 1978a). Transfer quotients were calculated from the enrichment ratio with ${ }^{15} \mathrm{~N}$ of the two pools of interest. Microbial contribution to abomasal NAN was calculated thus with NAN enrichment at the abomasum obtained according to Dixon (1978).

\section{Statistical design and analysis}

A randomized complete block design was used for this experiment with three treatments (diets) and six blocks (sheep). The effects of diets and animals were separated by analysis of variance. Treatment means were compared with their least significant differences (Steel \& Torrie, 1980).

\section{RESULTS}

Voluntary DM intakes (g/d) were 897,1149 and 1225 for diets A, B and C respectively (Table 2). Intake was limited to $90 \%$ ad lib. during the digestion and isotope study sections of each period (days 11-28). The standard error of the mean for ad lib. DM intake recorded over $4 \mathrm{~d}$ was $6.4-33.0 \mathrm{~g} / \mathrm{d}$ (mean 17.6) (for the eighteen sheep periods). Feeding the sheep at $90 \%$ ad lib. intake was effective in eliminating between-day variation in DM intakes during the digestion and isotope studies.

DM and OM intakes ( $90 \%$ ad lib.) increased significantly from diet $\mathrm{A}$ to diet B $(28 \%)$, with a further non-significant $(P>0.05)$ increase from diet $\mathrm{B}$ to $\operatorname{diet} \mathrm{C}(8 \%)$ (Table 2$)$. Digestibility of OM did not differ $(P>0.05)$ between diets so that intakes of digestible $\mathrm{OM}$ and quantities of $\mathrm{OM}$ digested in the stomach were increased $(P<0.05)$ with urea supplementation (Table 2).

Rumen DM pool size increased significantly $(P<0.05)$ with urea supplementation and rumen liquid pool size also increased, though not significantly (Table 3). MRT of ${ }^{103} \mathrm{Ru}-\mathrm{P}$ in the rumen decreased $(P<0.05)$ from diet $\mathrm{A}$ to diet $\mathrm{C}$ and there was a non-significant decrease in the MRT of ${ }^{51}$ CrEDTA (Table 3). The double-marker method requires that the markers used be distributed evenly throughout their respective phases (Faichney, 1975a). However, ${ }^{103} \mathrm{Ru}-\mathrm{P}$ is not evenly distributed throughout the particulate matter (Faichney, (1982) so that reconstitution factors depending on this marker may not adequately correct for relatively large sampling errors (Faichney, 1982; Egan \& Doyle, 1984). Accordingly, where reconstitution factors for abomasal digesta were greater than $0 \cdot 2-0 \cdot 3$, the faecal output of ADL was compared with its abomasal flow assuming there was no post-rumen disappearance of ADL (Fahey \& Jung, 1983). It was concluded that, for thirteen of eighteen sheep periods, ${ }^{103} \mathrm{Ru}-\mathrm{P}$ was unsatisfactory and that, for consistency, indigestible ADL should be used as the second marker for all periods.

NAN apparently digested in the intestines increased $(P<0.05)$ from diet $\mathrm{A}$ to diet $\mathrm{C}$ (Table 4). Similar proportional increases in $\mathrm{N}$ retention were observed but these differences were not significant due to the low precision of this measurement (Table 4). Rumen $\mathrm{NH}_{3}-\mathrm{N}$ 
Table 2. Digestion of organic matter $(O M)$ in the rumen and whole tract of sheep given alkali-treated wheat straw plus different levels of urea

\begin{tabular}{|c|c|c|c|c|}
\hline $\begin{array}{l}\text { Diet } \ldots \\
\text { Urea-nitrogen added (g/kg dry matter (DM)) }\end{array}$ & $\begin{array}{c}\text { A } \\
3 \cdot 5\end{array}$ & $\begin{array}{c}\text { B } \\
5 \cdot 9\end{array}$ & $\begin{array}{c}C \\
11 \cdot 6\end{array}$ & $\begin{array}{l}\mathrm{SE} \text { of } \\
\text { means }\end{array}$ \\
\hline Ad lib. DM intake* $(\mathrm{g} / \mathrm{d})$ & 897 & 1149 & 1225 & $-\dagger$ \\
\hline DM intake $(90 \%$ ad lib. $)(\mathrm{g} / \mathrm{d})$ & $808^{\mathrm{a}}$ & $1034^{\mathrm{b}}$ & $1102^{b}$ & $80 \cdot 2$ \\
\hline OM intake $(90 \%$ ad lib. $)(\mathrm{g} / \mathrm{d})$ & $705^{\mathrm{a}}$ & $913^{\mathbf{b}}$ & $973^{\mathrm{b}}$ & $69 \cdot 4$ \\
\hline Apparent $\mathrm{OM}$ digestibility & 0.61 & $0.59^{\mathrm{a}}$ & $0.61^{a}$ & 0.023 \\
\hline Digestible OM intake $(\mathrm{g} / \mathrm{d})$ & $434^{\mathrm{a}}$ & $534^{\mathrm{b}}$ & $592^{\mathrm{b}}$ & $41 \cdot 7$ \\
\hline $\mathrm{OM}$ apparently digested in the stomach $(\mathrm{g} / \mathrm{d})$ & $312^{\mathrm{a}}$ & $406^{\mathrm{ab}}$ & $454^{\mathrm{b}}$ & $46 \cdot 8$ \\
\hline $\begin{array}{l}\text { Proportion of digestible OM apparently } \\
\text { digested in the stomach }\end{array}$ & $0 \cdot 71^{\mathrm{a}}$ & $0 \cdot 77^{\mathrm{a}}$ & $0.75^{\mathrm{a}}$ & 0.058 \\
\hline
\end{tabular}

a, b Values with unlike superscript letters within rows differed significantly $(P<0.05)$.

* Each value is the mean of six sheep over $4 \mathrm{~d}$.

+ Variability discussed on p. 500 .

Table 3. Rumen pool sizes and mean retention times $(M R T)$ for sheep given alkali-treated wheat straw plus different levels of urea

\begin{tabular}{|c|c|c|c|c|}
\hline $\begin{array}{l}\text { Diet } \ldots \\
\text { Urea-nitrogen added (g/kg dry matter (DM)) }\end{array}$ & $\begin{array}{c}\text { A } \\
3 \cdot 5\end{array}$ & $\begin{array}{c}\text { B } \\
5 \cdot 9\end{array}$ & $\begin{array}{c}\mathrm{C} \\
11 \cdot 6\end{array}$ & $\begin{array}{l}\text { SE of } \\
\text { means }\end{array}$ \\
\hline Apparent rumen DM pool (g) (from $\left.{ }^{109} \mathrm{Ru}\right)$ & $555^{\mathrm{a}}$ & $665^{\mathrm{b}}$ & $767^{\mathrm{e}}$ & $17 \cdot 1$ \\
\hline Apparent rumen liquid pool ( $\mathrm{kg}$ ) (from ${ }^{51} \mathrm{Cr}$ ) & $4 \cdot 62^{a}$ & $5 \cdot 45^{\mathrm{a}}$ & $5 \cdot 50^{\mathrm{a}}$ & 0.404 \\
\hline${ }^{103} \mathrm{Ru}$ MRT in rumen (h) & $19 \cdot 5^{\mathrm{a}}$ & $18 \cdot 3^{\mathrm{ab}}$ & $16 \cdot 4^{\mathrm{b}}$ & $1 \cdot 27$ \\
\hline${ }^{51} \mathrm{Cr} \mathrm{MRT}$ in rumen (h) & $13 \cdot 0^{\mathrm{a}}$ & $11 \cdot 1^{\mathrm{a}}$ & $10 \cdot 5^{\mathrm{a}}$ & $1 \cdot 50$ \\
\hline
\end{tabular}

a, b.c Values with unlike superscript letters within rows differed significantly $(P<0 \cdot 05)$.

Table 4. Intake and digestion of nitrogen in sheep given alkali-treated wheat straw plus different levels of urea

\begin{tabular}{|c|c|c|c|c|}
\hline $\begin{array}{l}\text { Diet } \ldots \\
\text { Urea-nitrogen added }(\mathrm{g} / \mathrm{kg} \text { dry matter }) \quad \ldots\end{array}$ & $\begin{array}{c}A \\
3 \cdot 5\end{array}$ & $\begin{array}{c}\text { B } \\
5.9\end{array}$ & $\begin{array}{c}C \\
11.6\end{array}$ & $\begin{array}{l}\text { SE of } \\
\text { means }\end{array}$ \\
\hline $\mathrm{N}$ intake $(\mathrm{g} / \mathrm{d})$ & $7 \cdot 1^{\mathrm{a}}$ & $11 \cdot 5^{\mathrm{b}}$ & $18 \cdot 6^{\mathrm{c}}$ & $0 \cdot 91$ \\
\hline $\mathrm{N}$ disappearing in stomach $(\mathrm{g} / \mathrm{d})$ & $-2 \cdot 7^{a}$ & $-1 \cdot 7^{\mathrm{a}}$ & $2 \cdot 6^{\mathrm{b}}$ & $1 \cdot 10$ \\
\hline NAN leaving abomasum $(\mathrm{g} / \mathrm{d})$ & $9 \cdot 6^{\mathrm{a}}$ & $12 \cdot 7^{b}$ & $14 \cdot 8^{b}$ & $1 \cdot 21$ \\
\hline NAN apparently digested in intestines $(\mathrm{g} / \mathrm{d})$ & $5 \cdot 9^{\mathrm{a}}$ & $8 \cdot 0^{2 \mathrm{~b}}$ & $9 \cdot 5^{b}$ & 0.82 \\
\hline Faecal $N$ output $(g / d)$ & $3.7^{\mathrm{a}}$ & $4 \cdot 7^{\mathrm{ab}}$ & $5 \cdot 3^{b}$ & $0 \cdot 48$ \\
\hline Urinary $N$ output $(g / d)$ & $2 \cdot 5^{\mathrm{a}}$ & $5 \cdot 5^{b}$ & $11 \cdot 6^{\mathrm{c}}$ & $0 \cdot 58$ \\
\hline Apparent $N$ retention $(\mathrm{g} / \mathrm{d})$ & $0.9^{\mathrm{a}}$ & $1 \cdot 4^{\mathrm{a}}$ & $1 \cdot 8^{\mathrm{a}}$ & $0 \cdot 50$ \\
\hline
\end{tabular}

NAN, non-ammonia-N.

a, b, c Values with unlike superscript letters within rows differed significantly $(P<0.05)$.

and blood urea-N concentrations increased $(P<0.05)$ with urea supplementation (Table 5). Total microbial $\mathrm{N}$ leaving the abomasum increased significantly $(P<0.05)$ but because of the larger quantities of OM apparently digested in the rumen on diets $B$ and $C$, net efficiency of microbial protein synthesis did not differ between diets $(P>0.05)$ (Table 5). Bacterial and protozoal contributions to microbial protein reaching the duodenum did not 
Table 5. Blood urea, rumen ammonia and microbial protein synthesis in sheep given alkali-treated wheat straw plus different levels of urea

\begin{tabular}{|c|c|c|c|c|}
\hline $\begin{array}{l}\text { Diet } \ldots \\
\text { Urea-nitrogen added }(\mathrm{g} / \mathrm{kg} \text { dry matter }) \quad \ldots\end{array}$ & $\begin{array}{c}\mathrm{A} \\
3.5\end{array}$ & $\begin{array}{c}\text { B } \\
5 \cdot 9\end{array}$ & $\begin{array}{c}\mathrm{C} \\
11 \cdot 6\end{array}$ & $\begin{array}{l}\text { SE of } \\
\text { means }\end{array}$ \\
\hline Rumen $\mathrm{NH}_{3}-\mathrm{N}(\mathrm{mg} / \mathrm{l})$ & $37^{\mathrm{a}}$ & $107^{\mathrm{b}}$ & $184^{\circ}$ & $12 \cdot 6$ \\
\hline Rumen $\mathrm{NH}_{3}-\mathrm{N}$ pool (mg) & $172^{\mathrm{a}}$ & $581^{\mathrm{b}}$ & $1006^{c}$ & $70 \cdot 0$ \\
\hline Blood urea-N (mg/l) & $41^{\mathrm{a}}$ & $92^{\mathrm{b}}$ & $152^{\mathrm{c}}$ & $6 \cdot 7$ \\
\hline $\begin{array}{l}\text { Microbial N leaving abomasum (g/d) } \\
\left.\text { (from }{ }^{15} \mathrm{~N}\right)\end{array}$ & $6 \cdot 8^{\mathrm{a}}$ & $9 \cdot 6^{b}$ & $10 \cdot 7^{\mathrm{b}}$ & 0.91 \\
\hline Microbial $\mathrm{N}$ in abomasal NAN (from ${ }^{15} \mathrm{~N}$ ) & $0 \cdot 71^{\mathrm{a}}$ & $0 \cdot 76^{\mathrm{a}}$ & $0.73^{\mathrm{a}}$ & 0.035 \\
\hline $\begin{array}{l}\text { Bacterial } N \text { in abomasal NAN (from } \\
\text { DAPA: } \mathbf{N} \text { ) }\end{array}$ & $0 \cdot 56^{\mathrm{a}}$ & $0.67^{\mathrm{a}}$ & $0.67^{\mathrm{a}}$ & 0.061 \\
\hline $\begin{array}{l}\text { Protozoal } N \text { in abomasal NAN (from } \\
\text { difference) }\end{array}$ & $0 \cdot 15^{a}$ & $0.09^{\mathrm{a}}$ & $0.05^{\mathrm{a}}$ & 0.068 \\
\hline $\begin{array}{l}\text { Net efficiency of microbial protein synthesis } \\
\text { (g N/kg OMADR) }\end{array}$ & $24 \cdot 2^{\mathrm{a}}$ & $23 \cdot 7^{\mathrm{a}}$ & $25 \cdot 3^{a}$ & $4 \cdot 37$ \\
\hline
\end{tabular}

NAN, non- $\mathrm{NH}_{3}-\mathrm{N}$; DAPA, diaminopimelic acid; OMADR, organic matter apparently digested in the rumen. a, b, c Values with unlike superscript letters within rows differed significantly $(P<0.05)$.

Table 6. Transfers of nitrogen between rumen ammonia, blood urea and rumen microbial $N$ pools in sheep given alkali-treated wheat straw plus different levels of urea

\begin{tabular}{|c|c|c|c|c|}
\hline $\begin{array}{l}\text { Diet } \ldots \\
\text { Urea-N added ( } \mathrm{g} / \mathrm{kg} \text { dry matter) }\end{array}$ & $\begin{array}{c}\text { A } \\
3 \cdot 5\end{array}$ & $\begin{array}{c}\text { B } \\
5 \cdot 9\end{array}$ & $\begin{array}{c}\mathrm{C} \\
11 \cdot 6\end{array}$ & $\begin{array}{l}\text { SE of } \\
\text { means }\end{array}$ \\
\hline Irreversible loss of rumen $\mathrm{NH}_{3}-\mathrm{N}(\mathrm{g} / \mathrm{d})$ & $15 \cdot 5^{\mathrm{a}}$ & $17 \cdot 7^{\mathrm{ab}}$ & $21 \cdot 0^{\mathrm{b}}$ & $2 \cdot 18$ \\
\hline $\begin{array}{l}\text { Proportion of blood urea- } \mathrm{N} \text { derived from } \\
\text { rumen } \mathrm{NH}_{3}-\mathrm{N}\end{array}$ & $0.56^{\mathrm{a}}$ & $0.65^{\mathrm{a}}$ & $0.56^{a}$ & 0.066 \\
\hline $\begin{array}{l}\text { Proportion of microbial } \mathrm{N} \text { derived from } \\
\text { rumen } \mathrm{NH}_{3}-\mathrm{N}\end{array}$ & $1 \cdot 05^{\mathrm{a}}$ & $0.95^{\mathrm{a}}$ & $0.91^{\mathrm{a}}$ & $0 \cdot 157$ \\
\hline Irreversible loss of blood urea-N $(\mathrm{g} / \mathrm{d})$ & $5 \cdot 2^{a}$ & $8 \cdot 6^{b}$ & $14 \cdot 7^{\mathrm{c}}$ & 0.72 \\
\hline $\begin{array}{l}\text { Proportion of rumen } \mathrm{NH}_{3}-\mathrm{N} \text { derived from } \\
\text { blood urea-N }\end{array}$ & $0 \cdot 22^{\mathrm{a}}$ & $0 \cdot 23^{a}$ & $0 \cdot 11^{\mathrm{b}}$ & 0.021 \\
\hline $\begin{array}{l}\text { Proportion of microbial } \mathrm{N} \text { derived from } \\
\text { blood urea-N }\end{array}$ & $0 \cdot 31^{2}$ & $0 \cdot 21^{\mathrm{b}}$ & $0 \cdot 12^{\mathrm{c}}$ & 0.018 \\
\hline
\end{tabular}

$\mathrm{NAN}$, non- $\mathrm{NH}_{3}-\mathrm{N}$.

$a, b, c$ Values with unlike superscript letters within rows differed significantly $(P<0.05)$.

differ $(P>0.05)$; standard errors were large for these estimates. The proportion of NAN leaving the abomasum contributed by microbial $\mathrm{N}$ was similar $(P>0.05)$ for all diets (Table 5). The proportions of blood urea- $\mathrm{N}$ and microbial $\mathrm{N}$ derived from rumen $\mathrm{NH}_{3}$ did not differ $(P>0.05)$ between diets (Table 6), with the latter estimates being close to unity. The proportions of rumen $\mathrm{NH}_{3}-\mathrm{N}(0.22,0.23$ and 0.11 for diets $\mathrm{A}, \mathrm{B}$ and $\mathrm{C}$ respectively) and microbial $\mathrm{N}(0.31,0.21$ and 0.12 for diets $\mathrm{A}, \mathrm{B}$ and $\mathrm{C}$ respectively) derived from blood urea decreased $(P<0.05)$ with urea supplementation.

Absorption of rumen $\mathrm{NH}_{3}-\mathrm{N}$ increased significantly $(P<0.05)$ with increased dietary urea, while entry of blood urea-N into the rumen $\mathrm{NH}_{3}-\mathrm{N}$ pool was lower $(P<0.05)$ on diet $\mathrm{C}$ than on other diets (Fig. 1). Net transfers of blood urea-N into the rumen $\mathrm{NH}_{3}-\mathrm{N}$ pool (estimated as the difference between the transfers between these two pools) were 0.4 , 

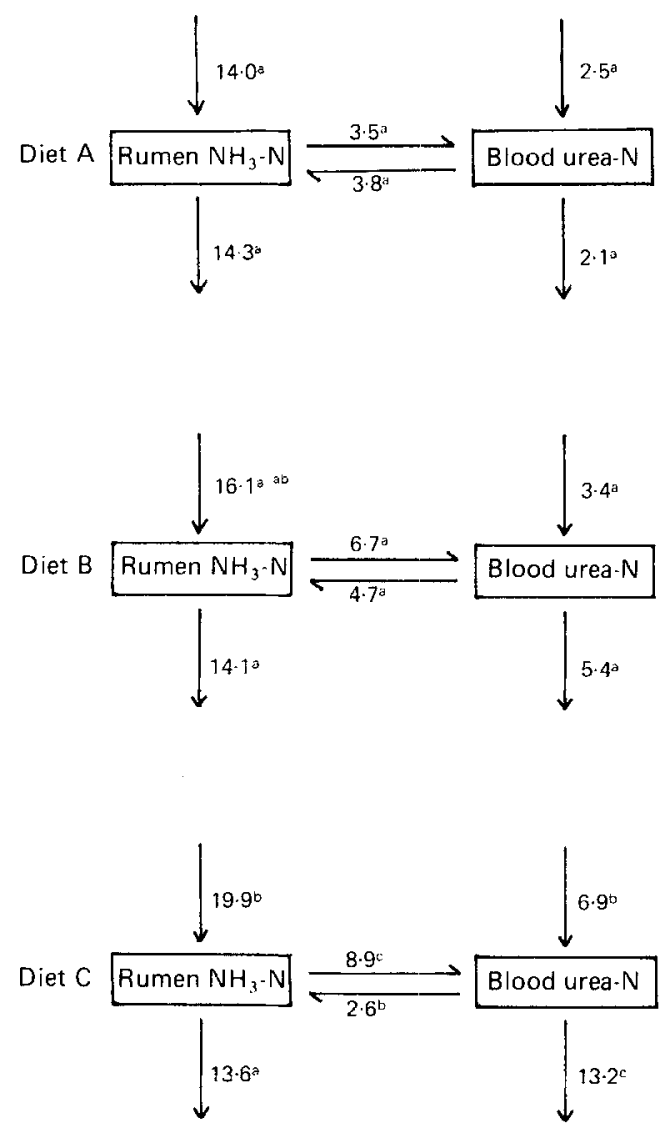

Fig. 1. Nitrogen transactions $(\mathrm{g} \mathrm{N} / \mathrm{d})$ in the rumen and tissues of sheep given diets comprising alkali-treated wheat straw supplemented with 3.5 (diet A), 5.9 (diet B) and 11.6 (diet C) $\mathrm{g}$ urea-N/kg dry matter. a, b, cValues with unlike superscript letters differed significantly $(P<0.05)$ between the diets with respect to the individual fluxes of $\mathrm{N}$-containing moieties.

$-2 \cdot 0$ and $-6 \cdot 3 \mathrm{~g} / \mathrm{d}$ for diets $\mathrm{A}, \mathrm{B}$ and $\mathrm{C}$ respectively with all differences being significant $(P<0.05)$ (SEM 0.84).

\section{DISCUSSION}

Proportion of microbial $\mathrm{N}$ derived from rumen $\mathrm{NH}_{3}$

The average proportion of microbial $\mathrm{N}$ derived from rumen $\mathrm{NH}_{3}$ for the three diets was 0.97 and no mean value was significantly different $(P<0.05)$ from $1 \cdot 0$. If rumen $\mathrm{NH}_{3}$ consists of a single well-mixed pool, this proportion cannot exceed $1 \cdot 0$. The highest published value is that of Hobson et al. (1968) who reported that one rumen bacterial isolate formed $93 \%$ of its cellular $\mathrm{N}$ from $\mathrm{NH}_{3}$. Although most of the dietary $\mathrm{N}$ was urea- $\mathrm{N}$ so that a very large proportion of microbial $\mathrm{N}$ would have been derived from the $\mathrm{NH}_{3}$ pool, at least a small proportion must have come from other sources. Errors associated with estimation of plateau ${ }^{15} \mathrm{~N}$ enrichments of the rumen $\mathrm{NH}_{3}-\mathrm{N}$ or microbial $\mathrm{N}$ pools are the most likely reason for overestimation of this factor, since errors associated with determination of sample enrichments on the mass spectrometer are minimal. The microbial $\mathrm{N}$ pool is much larger than the rumen $\mathrm{NH}_{3}-\mathrm{N}$ pool and coefficients of variation of plateau enrichment estimates for these pools can be in the region of 5 and $10-40 \%$ respectively (J. V. Nolan, 
personal communication). Thus more serious errors may have occurred in determining true rumen $\mathrm{NH}_{3}-\mathrm{N}$ enrichment.

\section{Enrichments of microbial- $\mathrm{N}$ and abomasal $\mathrm{NH}_{3}-\mathrm{N}$}

In determining enrichments and hence flows of microbial $\mathrm{N}$, it was assumed that, providing sufficient time was allowed for microbial exchanges in the rumen to reach equilibrium, protozoal enrichment would be the same as that of bacteria samples and that bacterial plateau enrichment would represent overall microbial plateau enrichment (Beever et al. 1974). Deviations from these assumptions might be expected because protozoa assimilate ${ }^{15} \mathrm{~N}$ from labelled rumen $\mathrm{NH}_{3}$ more slowly than do bacteria (Abe \& Kandatsu, 1969). However, this should introduce little error since protozoa comprised only a small proportion of microbial $\mathrm{N}$ leaving the rumen.

Abomasal NAN enrichment was determined by measuring enrichments of digesta and fluid samples, calculating true digesta enrichment and subtracting a value for enrichment of rumen $\mathrm{NH}_{3}-\mathrm{N}$. The assumption that abomasal $\mathrm{NH}_{3}-\mathrm{H}$ enrichment was equal to that of rumen $\mathrm{NH}_{3}-\mathrm{N}$ is not strictly true (J. V. Nolan, personal communication) but would have little effect on estimates of NAN enrichment since the quantities of abomasal $\mathrm{NH}_{3}-\mathrm{N}$ were low.

\section{Validity of assumptions for ${ }^{15} \mathrm{~N}$ tracer methodology}

The intravenous and intraruminal infusions of ${ }^{15} \mathrm{~N}$ had to be administered separately, with sufficient time between for ${ }^{15} \mathrm{~N}$ abundance in all pools to return to background levels. An inherent assumption was that conditions were identical during both infusions for a particular sheep period. While this can never be completely true, a number of indices provide an indication of the validity of this assumption. DM intakes $(90 \%$ ad lib.) were steady during the digestion and isotope experimental study periods for individual sheep (see p. 500). Rumen $\mathrm{NH}_{3}-\mathrm{N}$ and blood urea-N concentrations varied little between the three bulked samples collected for background abundance and, during each of the ${ }^{15} \mathrm{~N}$ infusions, within periods. Coefficients of variation for these estimates of rumen $\mathrm{NH}_{3}-\mathrm{N}$ and blood urea- $\mathrm{N}$ ranged from 0.7 to $40.9 \%$ (mean $12.7 \%$ ) and from 0.9 to $29.0 \%$ (mean $13.0 \%$ ) respectively.

\section{Transfer of blood urea- $N$ to the rumen}

Assuming salivary urea-N concentration is 0.60 of that in blood (Bailey \& Balch, 1961; Somers, 1961) and total salivary flow was 11 litres/d (average reported by Kay (1960)), contributions of salivary urea- $\mathrm{N}$ to the rumen were estimated as 0.3 (diet A), 0.6 (diet B) and 1.0 (diet $\mathrm{C}$ ) $\mathrm{g} \mathrm{N} / \mathrm{d}$. Although these are only approximations, it would appear that all blood urea- $\mathrm{N}$ transferred to the rumen cannot be accounted for by saliva alone, since these values represent only 8,13 and $38 \%$ of the total transfer measured (diets A, B and C respectively). Houpt (1959) reported that only $6 \%$ of urea entering the washed rumen of sheep was in saliva. Other early studies with rumen preparations or pouches (see Houpt, 1970) have also concluded that large amounts of blood urea-N cross the rumen wall. Such studies, however, are often questionable due to unphysiological conditions. Varady et al. (1979) calculated that $12.7 \mathrm{~g}$ urea-N/d was transferred to the forestomachs of sheep given a roughage-concentrate diet, of which only $15 \%$ was attributed to saliva. Where sheep were given brome grass pellets (Kennedy \& Milligan, 1978 b), substantial quantities of urea-N entered across the rumen wall. In contrast to these findings, in sheep given lucerne chaff (Nolan \& Leng, 1972) or wheat straw (Nolan \& Stachiw, 1979), most or all of the blood urea- $\mathrm{N}$ entering the rumen could be accounted for by saliva. Arterio-venous differences of urea in blood across the rumen of sheep given lucerne also indicated little or no movement of urea through the epithelium into the rumen (Hecker \& Nolan, 1971).

The differences in routes of urea recycling have not been fully explained. The quantity 
of salivary urea- $\mathrm{N}$ entering the rumen is influenced by total salivary output and blood urea-N concentration, both of which are largely dependent on diet. Kennedy \& Milligan $(1978 d)$ suggested that the low rates of blood urea transfer observed in sheep fed on lucerne chaff (Nolan \& Leng, 1972; Nolan et al. 1976) and native pastures (Norton et al. 1978) were due to transfer being limited by either high rumen $\mathrm{NH}_{3}$ concentration or low intake of digestible $\mathrm{OM}$. In the latter two studies, rumen $\mathrm{NH}_{3}$ levels were lower than that in sheep fed on brome grass diets (Kennedy \& Milligan, 1978c) but recycling was much lower (0.6 and $1.0 \mathrm{~g} \mathrm{~N} / \mathrm{d}$ respectively). High recycling values, including those obtained for cattle (Hart et al. 1982), may be due in part to the relatively short duration of the experiments. Over a longer period of time, such as occurs during $\mathbf{N}$ deficiency in field situations, labile protein reserves diminish.

Total entries of blood urea- $\mathrm{N}$ in the present experiment ranged from 2.6 to $4.7 \mathrm{~g} / \mathrm{d}$. However, with regard to the overall $\mathrm{N}$ economy of the ruminant, it is more important to consider the net transfer to the rumen. On diet $\mathrm{A}$, there was a marginal, non-significant net transfer from the blood urea- $\mathrm{N}$ pool to the rumen $\mathrm{NH}_{3}$ pool $(0.4 \mathrm{~g} \mathrm{~N} / \mathrm{d})$. This appears to be the only case in the literature where a positive net transfer has been reported. Recently, a net value of only $-0.4 \mathrm{~g}$ urea- $\mathrm{N} / \mathrm{d}$ transferred to the rumen was reported for sheep given a low-N dried-grass diet (Siddons et al. 1985). Net $\mathbf{N}$ transfers for diets $\mathrm{B}$ and $\mathrm{C}$ were negative. There was substantial movement of $\mathrm{NH}_{3}$ from the rumen even on diet $\mathrm{A}$ $(3.5 \mathrm{~g} \mathrm{~N} / \mathrm{d})$ where rumen $\mathrm{NH}_{3}$ concentration was extremely low. Hence, the value to the animal of urea- $\mathrm{N}$ entering the rumen was diminished by this concurrent loss of $\mathrm{NH}_{3}$ from the rumen.

\section{The significance of urea recycling}

The quantities of blood urea- $\mathrm{N}$ apparently incorporated into microbial $\mathrm{N}$ were $2 \cdot 1,2 \cdot 1$ and $1.3 \mathrm{~g} / \mathrm{d}$ for diets $\mathrm{A}, \mathrm{B}$ and $\mathrm{C}$ respectively. Corresponding values reported for sheep given brome grass pellets and lucerne pellets were 3.2 and $0.6 \mathrm{~g} / \mathrm{d}$ respectively (Kennedy \& Milligan, 1977). From diet $\mathbf{C}$ to diet $\mathbf{B}$ and $\operatorname{diet} \mathrm{B}$ to $\operatorname{diet} \mathrm{A}$, there were significant $(P<0.05)$ increases in the proportion of microbial $\mathrm{N}$ flowing at the abomasum which was derived from blood urea- $\mathrm{N}$. Hence, where dietary $\mathrm{N}$ was low, transfer of endogenous urea- $\mathrm{N}$ to the rumen made a relatively larger contribution to the microbial protein available to the small intestine. This compensated partially for the smaller amount of $\mathrm{NH}_{3}-\mathrm{N}$ derived from exogenous $\mathrm{N}$ sources that was available in the rumen for production of microbial protein. Entry of blood urea- $\mathrm{N}$ into the rumen was equivalent to $0.55,0.40$ and $0 \cdot 14$ of $\mathrm{N}$ intake for diets $\mathrm{A}, \mathrm{B}$ and $\mathrm{C}$ respectively, again indicating the greater significance of blood urea-N where $\mathrm{N}$ intake was low. On diets $\mathrm{A}$ and $\mathrm{B}$, blood urea also made a significantly greater $(P<0.05)$ proportional contribution to the rumen $\mathrm{NH}_{3}-\mathrm{N}$ pool than that on diet $\mathrm{C}$. This source of $\mathrm{N}$ will only be of value to the ruminant if $\mathrm{NH}_{3}$ is limiting fermentative processes and microbial growth as appears to have been the case on diet $\mathrm{A}$.

Ruminants are able to survive under conditions of nutritional stress though they often lose weight. Their ability to conserve $\mathrm{N}$ is evidenced partially by the fact that they excrete less $\mathrm{N}$ during periods of dietary $\mathrm{N}$ deficiency (see review by Harmeyer \& Martens, 1980) because a greater proportion of blood urea- $\mathrm{N}$ is recycled to the rumen for re-utilization by microbes. This conservation mechanism is certainly evident on diet $\mathrm{A}$ as indicated by significantly lower excretion of urinary $\mathrm{N}$ (Fig. 1). However, because sheep and cattle grazing poor-quality forages often cannot maintain body-weight without $\mathrm{N}$ supplementation, it appears that recycling of urea- $\mathrm{N}$ under such circumstances is unable to meet maintenance requirements.

Alkali-treated wheat straw was chosen as the basal roughage in the present experiment because of its moderate-energy but low-protein content. Estimated metabolizable energy (ME) intakes (Ministry of Agriculture, Fisheries and Food, 1975) ranged from 6.7 to 
$9 \cdot 2 \mathrm{MJ} / \mathrm{d}$, so it is unlikely that the reduced DM intake observed on diet $\mathrm{A}$ was due to low dietary energy concentration. Significant intake responses to exogenous urea supplementation were observed because on $\operatorname{diet} A$, where intake was extremely low, the sheep had a limited capacity to recycle $\mathrm{N}$ to the rumen. Therefore, although blood urea- $\mathrm{N}$ entering the rumen was significantly (though not dramatically) greater on diets $\mathrm{A}$ and $\mathrm{B}$ than on diet $\mathrm{C}$, this increase was insufficient to compensate for the relative deficiency of dietary $\mathrm{N}$.

It was originally intended that diet A would contain no urea. In preliminary trials, sheep were able to maintain a reasonable intake $(600-800 \mathrm{~g} \mathrm{DM} / \mathrm{d})$ for only about 2 weeks after which they almost stopped eating. This presumably occurred when the animals reached a point where their rumen microbes could no longer obtain sufficient $\mathrm{N}$ from either dietary or endogenous sources for fermentation. This inhibition of voluntary intake is not surprising since the alkali-treated straw alone contained only $0.53 \mathrm{~g} \mathrm{~N} / \mathrm{kg} \mathrm{DM}$ or $3.3 \mathrm{~g}$ crude protein $(\mathrm{N} \times 6 \cdot 25) / \mathrm{kg}$. These observations also point to the inadequate nature of urea recycling to the gastrointestinal tract under such conditions. Even when a small quantity of urea was sprayed onto the straw for the diet A used, there were some difficulties in achieving steady DM intakes over 4-week experimental periods.

The authors are very grateful to Dr J. V. Nolan for his advice on ${ }^{15} \mathrm{~N}$ techniques. They also thank Miss $\mathrm{H}$. Warren for experimental and laboratory assistance, and Mr E. Teleki for his technical contribution in ${ }^{15} \mathrm{~N}$ analysis. Financial support was provided by The Australian Meat Research Committee and The Australian Wool Corporation.

\section{REFERENCES}

Abe, M. \& Kandatsu, M. (1969). Japanese Journal of Zootechnical Science 40, 313-319.

Bailey, C. B. \& Balch, C. C. (1961). British Journal of Nutrition 15, 383-402.

Beever, D. E., Harrison, D. G., Thomson, D. J., Cammell, S. B. \& Osborn, D. F. (1974). British Journal of Nutrition 32, 99-112.

Binnerts, W. T., van't Klooster, A. Th. \& Frens, A. M. (1968). Veterinary Record 82, 470.

Chaney, A. L. \& Marbach, E. P. (1962). Clinical Chemistry 8, 120-132.

Dixon, R. M. (1978). Nitrogen metabolism in the large intestine of sheep. Ph.D. Thesis, University of New England, Armidale, NSW.

Downes, A. M. \& McDonald, I. W. (1964). British Journal of Nutrition 18, 153-162.

Egan, J. K. \& Doyle, P. T. (1984). Australian Journal of Agricultural Research 35, 279-291.

Fahey, G. C. Jr \& Jung, H. G. (1983). Journal of Animal Science 57, 220-225.

Faichney, G. J. (1975a). In Digestion and Metabolism in the Ruminant, pp. 277-291 [I. W. McDonald and A. C. I. Warner, editors]. Armidale: University of New England.

Faichney, G. J. (1975b). Australian Journal of Agricultural Research 26, 319-327.

Faichney, G. J. (1980). Australian Journal of Agricultural Research 31, 1129-1137.

Faichney, G. J. (1982). In Techniques in the Life Sciences, vol. P2, Techniques in Digestive Physiology P 211, pp. 33-44 [D. A. Titchen, editor]. County Clare: Elsevier.

Faichney, G. J. \& White, G. A. (1983). Methods for the Analysis of Feeds Eaten by Ruminants. Melbourne: CSIRO

Harmeyer, J. \& Martens, H. (1980). Journal of Dairy Science 63, 1707-1728.

Hart, F. J., Leibholz, J., Wadsworth, J. C. \& Teleki, E. (1982). Proceedings of the Nutrition Society of Australia 7, 200.

Hecker, J. F. \& Nolan, J. V. (1971). Australian Journal of Biological Sciences 24, 403-405.

Hobson, P. N., McDougall, E. 1. \& Summers, R. (1968). Journal of General Microbiology 50, i.

Houpt, T. R. (1959). American Journal of Physiology 197, 115-120.

Houpt, T. R. (1970). In Physiology of Digestion and Metabolism in the Ruminant, pp. 119-131 [A. T. Phillipson, editor]. Newcastle upon Tyne: Oriel Press.

Hutton, K., Bailey, F. J. \& Annison, E. F. (1971). British Journal of Nutrition 25, 165-173.

Kay, R. N. B. (1960). Journal of Physiology, London 150, 515-537.

Kennedy, P. M. \& Milligan, L. P. (1977). Proceedings of the Nutrition Society 36, 53A.

Kennedy, P. M. \& Milligan, L. P. (1978a). British Journal of Nutrition 39, 65-84.

Kennedy, P. M. \& Milligan, L. P. (1978b). British Journal of Nutrition 39, 105-117.

Kennedy, P. M. \& Milligan, L. P. (1978c). British Journal of Nutrition 40, 149-154. 
Kennedy, P. M. \& Milligan, L. P. (1978d). Canadian Journal of Animal Science 58, 814.

Ministry of Agriculture, Fisheries and Food (1975). Technical Bulletin no. 33, p. 65. London: H.M. Stationery Office.

Neutze, S. A., Faichney, G. J., Kellaway, R. C. \& Teleki, E. (1984). Proceedings of the Nutrition Society of Australia 9, 153.

Nolan, I. V. \& Leng, R. A. (1972). British Journal of Nutrition 27, 177-194.

Nolan, J. V., Norton, B. W. \& Leng, R. A. (1976). British Journal of Nutrition 35, 127-147.

Nolan, J. V. \& Stachiw, S. (1979). British Journal of Nutrition 42, 63-80.

Norton, B. W., Murray, R. M., Entwistle, K. W., Nolan, J. V., Ball, F. M. \& Leng, R. A. (1978). Austratian Journal of Agricultural Research 29, 595-603.

Siddons, R. C., Nolan, J. V., Beever, D. E. \& MacRae, J. C. (1985). British Journal of Nutrition 54, $175-187$.

Somers, M. (1961). Australian Journal of Experimental Biology and Medical Science 39, 145-156.

Steel, R. G. D. \& Torrie, J. H. (1980). Principles and Procedures of Statistics. Kogakusha Tokyo: McGraw-Hill Ltd.

Tan, T. N., Weston, R. H. \& Hogan, J. P. (1971). International Journal of Applied Radiation and Isotopes 22, 301-308.

Van Soest, P. J. (1963). Journal of the Official Association of Agricultural Chemists 46, 829-835.

Varady, J., Boda, K., Tasenov, K. \& Fejes, J. (1979). Annales de Recherches Vétérinaires 10, 448-450.

Weston, R. H. \& Hogan, J. P. (1967). Australian Journal of Agricultural Research 18, 789-801.

White, R. G., Steel, J. W., Leng R. A. \& Luick, J. R. (1969). Biochemical Journal 114, 203-214.

Wilson, B. W. (1966). Clinical Chemistry 12, 360-368. 